\title{
Pharmaciana
}

Vol.11, No.1, March 2021, Page. 69-80

ISSN: 2088 4559; e-ISSN: 24770256

DOI: $10.12928 /$ pharmaciana.v11i1.17511

\section{Booklet handout to improve glycemic control in type-2-DM patients and comparison with other models}

\author{
Daniek Viviandhari", Nora Wulandari, Nur Rahmi \\ Faculty of Pharmacy and Science, Universitas Muhammadiyah Prof. Dr. HAMKA, \\ Delima II Street, Klender, East Jakarta, Indonesia
}

Accepted: 06-04-2021

\begin{abstract}
Non-adherence is still a major issue in the management of diabetes in Indonesia which leads to complication problems. Medication adherence in diabetes mellitus is related to better glycemic control, better control of risk factors, lower risk of hospitalization, lower health care cost, and lower risk of mortality. Many educational models are applied to achieve the patient's glycemic control. There were two research purposes in this study. The first one was to determine the booklet handout's effectiveness in improving glycemic control in type-2 diabetes mellitus patients in Malaka Jaya Primary Healthcare Centre, Jakarta. The second aim was to compare two different educational models, which were done simultaneously at Pondok Kelapa Primary Healthcare Centre and Duren Sawit Primary Healthcare Centre. A quasi-experimental study design was applied in these prospective studies. A total of 30 patients met the inclusion criteria. The intervention was a booklet handout that was given and presented to the respondent once every month for three months. The parameter used was the A1C (glycated hemoglobin). For patients exposed to booklet handout, $20.0 \%$ of them had the A1C level $<6.5 \%$ initially, then the A1C level $<6.5 \%$ significantly increased to $73.34 \%(\mathrm{p}=0.005)$. For patients who were given public counseling, the number of respondents who had the A1C level $<6.5 \%$ was $16.7 \%$, then the A1C percentage rose to $76.7 \%$ ( $\mathrm{p}=0.005$ ). Meanwhile, for patients who were educated with video, the A1C level $<6.5 \%$ was $6.67 \%$ initially, then the A1C level <6.5\% increased significantly to $90.0 \%(\mathrm{p}=0.005)$ in 12 weeks after the intervention. Either booklet handout, public counseling, or video are effective to improve glycemic control in type-2 diabetes mellitus patients.
\end{abstract}

Keywords: booklet handout, public counseling, educational video, comparison, A1C

\section{*Corresponding author:}

Daniek Viviandhari

Faculty of Pharmacy and Science, Universitas Muhammadiyah Prof. Dr. HAMKA

Delima II Street, Klender, East Jakarta, Indonesia

Email: daniek.viviandhari@uhamka.ac.id 


\section{INTRODUCTION}

Diabetes mellitus is defined as a chronic illness caused by an absolute deficiency of insulin (type-1 diabetes mellitus) or relative deficiency of insulin (type-2 diabetes mellitus) due to impaired insulin activity. The clinical characteristics are hyperglycemia and lipid and protein metabolism. These abnormalities result in the development of cardiovascular disease (Alldredge et al., 2013). Based on national data, the number of diabetes mellitus prevalence (based on clinician diagnose on population age $\geq 15$ years) has increased from $1.5 \%$ in 2013 to $2.0 \%$ in 2018 , where Jakarta occupies the highest prevalence (3.4\%) (Riskesdas, 2018).

Type-2 diabetes mellitus patients often receive multiple medications to control hyperglycemia and comorbidities such as hypertension. Medication adherence is one of the significant determinant factors of diabetes mellitus outcomes. Medication adherence in diabetes mellitus is related to better glycemic control, better control of risk factors, lower risk of hospitalization, lower health care cost, and lower risk of mortality (Care, 2019; Kirkman et al., 2015). The A1C measurement was used mainly in glycemic management, which showed the benefits of increased glycemic control in a previous study (Care, 2019).

Non-adherence is still a major issue in the management of diabetes in Indonesia which leads to many problems (Alfian et al., 2016; Nanda et al., 2018). Diabetes mellitus complications (microvascular and macrovascular) and extra cost to the health system are results of poor adherence to the treatment for diabetes mellitus (Geest and Sabaté, 2003). Some research in Indonesia showed that most patients exhibited low adherence (ranging from 44.1 to 53.8\%). Patients with low adherence tend to have uncontrolled glucose levels (Alfian et al., 2016; Nanda et al., 2018; Rasdianah et al., 2016). Some research conducted in another country stated that the level of nonadherence to diabetes mellitus medication was high. Around $45 \%$ patient fail to manage glycemic control (A1C level > 7\%). These findings emphasize the need for education to ensure medication adherence (Alqarni et al., 2019; Polonsky and Henry, 2016; Sharma et al., 2014).

Research conducted in South India stated that improved diabetes medication adherence reduces peripheral diabetic neuropathy severity. Patient education ought to be implemented to improve patient adherence. Health care professionals, including pharmacists, play a significant role in educating diabetes mellitus patients regarding therapy management (Samu et al., 2017).

The goal of education is to empower patients to be active and involved in their treatment and prevent complications (Contreras et al., 2017). Many educational models are applied to achieve patient compliance and patient's glycemic control, such as counseling, booklet handout, and educational video. Research stated that individual counseling is more effective in controlling glycemic index than group education (Fan et al., 2016). Another study conducted in Norwegia found that group-based diabetes self-management education increase clinical, lifestyle, and psychosocial outcomes (Steinsbekk et al., 2015).

The fact that the number of pharmacists in Indonesia's primary health care centers is limited encourages the search for appropriate and effective educational models for patients. Hence, this research aimed to compare the effectiveness of three different educational models (booklet handout, public counseling, and educational video) in improving glycemic control in type- 2 diabetes mellitus patients in three Primary Health Care Centers in Jakarta.

\section{MATERIALS AND METHOD \\ Materials}

The A1C level reader (i-Chroma TM) was the tool used in this research to collect data.

\section{Methods}

This study used a prospective method, and samples were collected with the total sampling method. This study was conducted at Malaka Jaya primary healthcare center from July 2017 to 
October 2017. The population of type-2 DM patients in the Malaka Jaya primary healthcare center was 65 patients; with the total sampling method, the respondents should be 65 patients, but only 30 patients were willing to follow until the end of the study. The participants of this study were type- 2 DM patients who joined the "Prolanis" program. Quasi-experimental research was designed to assess the impact of booklet handouts during the study period. During the 12 weeks of the study, the intervention was given three times. The A1C data were collected two times during the pre-test and post-test.

The inclusion criteria of this research were: adult patients ( $>18$ years old), experienced DM at least one year, speak and understand Bahasa Indonesia, fasting blood sugar level $>126 \mathrm{mg} / \mathrm{dL}$ in 3 months in a row, consume oral antidiabetic drugs (OAD), and visit the primary healthcare center for a check-up regularly. Fasting blood sugar levels were used in this study because A1C examination was rarely performed on patients at Malaka Jaya primary healthcare center. The exclusion criteria of this research were patients with gestational diabetes.

The research proposal received Ethical Approval from the Research Ethics Committee of Faculty of Medicine, University of Indonesia (protocol number 17-03-0285). After the research permit was granted from the primary healthcare center, the researchers conducted the patient screening. Patients were asked to sign an informed consent as a form of agreement to participate as research respondents.

Lifestyle characteristics are dietary habits, smoking, exercise, and herbs. Dietary habit in type-2 DM patients means people with DM need to understand the importance of regularity of meal schedules, types, and calorie content quantities (PERKENI, 2015). Exercise in type-2 DM patients means physical exercise done regularly 3-5 times per week (30-45 minutes each session). For 150 minutes per week, the pause between workouts should be less than two consecutive days (PERKENI, 2015). Smoking in patients with type-2 DM means patients smoked during the study period. Herbs' use means patients consumed herbal medicines that were empirically used to treat diabetes mellitus during the study period.

\section{Research procedure}

Patients who agreed to take part in the research filled out the informed consent form. The data were collected using the total sampling method. The samples were all respondents who followed the entire research process and met the inclusion criteria. The measurement of A1C levels (this is considered as the pre-test data) was done before the intervention.

Respondents were given booklet handout as a form of education intervention as many as three times during the study period ( 3 months). The booklet handout was given to patients during the "Prolanis" (Chronic Disease Control Program) meeting. Patients were asked to read the booklet once (in the forum) and were asked to ask questions if there are things that cannot be understood at that moment. Patients were also educated to reread at home. The booklet handout materials were divided into three sections: the first one was a general explanation of diabetes mellitus, diabetes mellitus complications (microvascular and macrovascular), pharmacotherapy of diabetes mellitus, and also about patient adherence; the second one was an explanation of diabetic diet plan and repeated explanation of pharmacotherapy of diabetes mellitus; the third one was an explanation of physical exercise plan and repeated explanation of pharmacotherapy of diabetes mellitus. The remeasurement of A1C levels (this is considered as the post-test data in the $3^{\text {rd }}$ month) was done after the intervention.

\section{Data Analysis}

A frequency distribution was analyzed descriptively. The variables assessed were the sociodemographic characteristics, the clinical characteristics, and the lifestyle characteristics. Statistical analysis using Wilcoxon's t-test was used to assess the changes in A1C level. Meanwhile, the Chi-Square test was performed to determine the correlation between the patient's 
characteristics and A1C level. Statistical Package for Social Sciences (SPSS) version 22.0 was used in this research.

\section{RESULT AND DISCUSSION}

Two prior studies have been published, i.e., the study of public counseling and educational video separately. This research has mainly discussed education with a booklet handout and also compare the three different educational models.

The population of diabetes mellitus patients in the Malaka Jaya primary healthcare center was 65 patients, but only 30 patients met the inclusion criteria.

\section{Patient characteristics}

Based on the sociodemographic characteristics shown in Table 1, the respondents' distribution showed most of the respondents with booklet handout were male (53.3\%). This data is different when compared to patients given education with public counseling and video, where most respondents were female $(63.3 \%$ and $76.7 \%$, respectively) (Viviandhari et al., 2018; Wulandari et al., 2020). The prevalence of type-2 DM showed that most of type-2 DM patients are females (Badan Penelitian dan Pengembangan Kesehatan, 2013). The majority of the patients were more than 60 years old $(90.0 \%)$. Similar results were found in patients with public counseling and video. Geriatric patients are at risk for type-2 diabetes mellitus development due to impaired pancreatic islet function and increased insulin resistance and aging (Kirkman et al., 2012). Most patients were in the middle levels of education $(60.0 \%)$. These data were different in all three primary health care. Based on a study held in Jakarta, the level of education and type-2 DM incidence had no significant correlation (Trisnawati and Setyorogo, 2013). Conversely, a study in China found that a low level of education was associated with a high incidence of diabetes (Shang et al., 2013). More than $85 \%$ of all respondents at three primary healthcare centers were unemployed.

Table 1. The sociodemographic characteristics

\begin{tabular}{llcc}
\hline & $\begin{array}{c}\text { The Sociodemographic } \\
\text { Characteristics }\end{array}$ & $\mathrm{n}=30$ & $\%$ \\
\hline Sex & Male & 16 & 53.3 \\
& Female & 14 & 46.7 \\
Age & $<60$ years & 3 & 10.0 \\
& $\geq 60$ years & 27 & 90.0 \\
Level of education & Low & 6 & 20.0 \\
& Middle & 18 & 60.0 \\
& High & 6 & 20.0 \\
Occupation & Unemployed & 28 & 93.3 \\
& Employed & 2 & 6.7 \\
\hline
\end{tabular}


Table 2. The clinical characteristics

\begin{tabular}{|c|c|c|c|}
\hline \multicolumn{2}{|c|}{ The Clinical Characteristics } & \multirow{2}{*}{$\begin{array}{c}\mathrm{n}=30 \\
12\end{array}$} & \multirow{2}{*}{$\begin{array}{c}\% \\
40.0\end{array}$} \\
\hline History/duration of & $<5$ years & & \\
\hline & $\geq 5$ years & 18 & 60.0 \\
\hline The numbers of & 1 & 14 & 46.7 \\
\hline $\begin{array}{l}\text { oral antidiabetic } \\
\text { drug }(\mathrm{OAD})\end{array}$ & $>1$ & 16 & 53.3 \\
\hline \multirow[t]{3}{*}{ Comorbidity } & No & 3 & 10.0 \\
\hline & 1 & 16 & 53.3 \\
\hline & 2 or more & 11 & 36.7 \\
\hline \multirow[t]{2}{*}{ Other medicines } & Yes & 27 & 90.0 \\
\hline & No & 3 & 10.0 \\
\hline \multirow{2}{*}{$\begin{array}{l}\text { Adverse Drug } \\
\text { Reaction }\end{array}$} & Yes & 5 & 16.7 \\
\hline & No & 25 & 83.3 \\
\hline
\end{tabular}

Clinical characteristics summarized in Table 2 showed that around $60 \%$ of the respondents had a history/duration of type-2 DM for $\geq 5$ years. Similar results were found on respondents who were educated with public counseling and even higher on respondents educated with video $(80 \%)$. A study in Kenya found out that patients with 2-10 years of diabetes mellitus $(\mathrm{OR}=2.07, \mathrm{CI}=$ 1.01- 4.22) were factors related to poor medication compliance (Waari et al., 2018). Another research claimed that the duration of DM was adversely associated with the patients' adherence (Elsous et al., 2017; Gimenes et al., 2009). Research in South West Ethiopia stated that patients who had diabetes for a long period were more likely to have poor glycemic control (Mamo et al., 2019). Most respondents received $>1$ oral antidiabetic drug (OAD) (53.3\%). The finding in Pondok Kelapa and Duren Sawit primary healthcare center reinforced these data. A combination of an oral antidiabetic drug can be used if needed; the main principle is the combined drugs should have a different mechanism (PERKENI, 2015). Usually, patients with a combination of OAD were those whose glycemic control was not well managed when using single therapy only. The majority of the respondents had one comorbidity (53.3\%). Data from respondents with educational videos were slightly different $(60.0 \%$ of patients had 2 or more comorbidities) (Wulandari et al., 2020). The most common comorbidity in this study was hypertension and found in two other primary healthcare centers. Hypertension increases the risk of diabetes mellitus complications (macrovascular and microvascular) (American Diabetes Association, 2003). Most of the respondents $(90.0 \%)$ used other drugs (similar data were found in 2 other primary healthcare centers). This condition was caused by comorbidities (in which more than $50 \%$ of patients in this study had at least one comorbidity). This also made the drug regimens even more complex, which further reduced the patient's compliance (Geest and Sabaté, 2003). In contrast, a research stated that patients on multiple medicines were reported to have high medication adherence rates regardless of the number of medicines taken (Grant et al., 2003). The efficacy of drug combinations in geriatrics has been shown in some clinical research. Monotherapy simplifies the medication regimen; combined therapies offer benefits, such as giving a lower risk of complications (macrovascular and microvascular) (Munger, 2010). There were only $16.7 \%$ of the patients who experienced side 
effects. This finding was less than what we found in Pondok Kelapa primary healthcare centre (26.7\%). Some of major side effects of antidiabetic drugs which were experienced by respondents are hypoglycemia and gastrointestinal disturbance (Chaudhury et al., 2017). A research explains that the major factors contributing to non-compliance are financial limitation (37.1\%) and side effect of the drug being experienced by the patients (29.2\%) (Wabe et al., 2011).

Table 3. The lifestyle characteristics

\begin{tabular}{llcc}
\hline The Lifestyle Characteristics & $\mathrm{n}=30$ & $\%$ \\
\hline Dietary habit & Adjusted & 27 & 90.0 \\
& Not adjusted & 3 & 10.0 \\
Smoking & Yes & 0 & 0 \\
& No & 30 & 100.0 \\
Exercise & Yes & 28 & 93.3 \\
& No & 2 & 6.7 \\
Herbs & Yes & 2 & 6.7 \\
& No & 28 & 93.3 \\
\hline
\end{tabular}

Table 3 represents the respondent's distribution based on lifestyle characteristics. Only posttest data were shown in this table. Adjusting dietary habits (including carbohydrate and sugar restriction) was applied to $90.0 \%$ of respondents. Type-2 DM patients need to restrict calorie intake to lose weight (DiPiro et al., 2015). Overall, all respondents in three primary healthcare centers claim to manage their diet (on post-test), and the number of patients who adjust their habit was increased compared to pre-test data. This finding indicated that the education given affects patients' behavior in dietary control. Patients should understand about diabetes mellitus and proper diet; therefore, the health care professional (including pharmacist) must inform the patients to change their food preparations and nutritional habits. Effective education about dietary habits may prevent diabetes complications (Sami et al., 2017). No respondents were smoking. Similar data were found in respondents who were given with educational video. There was only one respondent in Pondok Kelapa primary healthcare center who was smoking. The research was made to understand the relation between smoking and the risk of diabetes. Inflammation and oxidative stress caused by cigarette smoke increased the risk of diabetes. Smoking is also related to a high risk of abdominal obesity, which is already known as a significant risk factor for developing diabetes. Nicotine in some studies made insulin less effective. Smoking is also related to cardiovascular disease, retinopathy, and peripheral neuropathy (CDC, 2014; Chang, 2012). The Indonesian Association of Endocrinologists and The American Diabetes Association stated that exercise is a critical aspect in DM management (if nephropathy was absent). The recommendations vary depending on patient characteristics and health status. Exercise should be regularly done (3-5 times a week for about 3045 minutes each). Some types of exercise are walking, jogging, cycling, and swimming (Colberg et al., 2016; PERKENI, 2015). Only 6.7\% of respondents used herbal medicines. A similar result was seen on the patient with an educational video. According to a research, the effect on the A1C level using herbs which are known empirically as an antidiabetic agent was not significant since the information regarding the herb's duration, dose, and administration may be unclear (Puspitasari et al., 2013). 


\section{The effectiveness of booklet handout}

A1C level was the laboratory data used to measure type-2 DM patient's glycemic control. Glycemic management was mainly measured with the A1C test. The A1C level in DM management's primary target is $\leq 6.5 \%$ (American Diabetes Association (ADA), 2017). A1C demonstrates the benefits of better glycemic control. A1C reflects the average of glycemic over three months (Care, 2019). Some research stated that increasing medication adherence means improvements in A1C (Aikens and Piette, 2013; Alqarni et al., 2019; Gordon et al., 2018).

Table 4. The Mean A1C Levels (Pre-Test and Post-test)

\begin{tabular}{ccccc}
\hline The A1C levels & \multicolumn{2}{c}{$\begin{array}{c}\text { Before intervention (Pre- } \\
\text { test) }\end{array}$} & \multicolumn{2}{c}{$\begin{array}{c}\text { After intervention } \\
\text { (Post-test) }\end{array}$} \\
\cline { 2 - 5 } & $\mathrm{n}=30$ & $\%$ & $\mathrm{n}=30$ & $\%$ \\
\hline$<6.5 \%$ & 6 & 20.0 & 22 & 73.3 \\
$\geq 6.5 \%$ & 24 & 80.0 & 8 & 26.7 \\
Mean A & \multicolumn{2}{c}{$7,56 \pm 1,17$} & $5,67 \pm 1,07$ & \\
$p$ & \multicolumn{2}{c}{$0,005^{\mathrm{a}}$} & & \\
\hline
\end{tabular}

$\mathrm{SD}=$ standard deviation

${ }^{\mathrm{a}}$ The statistically significant differences according to the paired t-test

The measurement of A1C level on this research was conducted at the Indonesian Centre for Health Laboratory, Ministry of Health (ISO/IEC 17025:2005 accredited). The analysis used was the HPLC method (High-Performance Liquid Chromatography) (Sacks et al., 2011).

Based on Table 4, as much as $80.0 \%$ of patients still had high levels of A1C $(\geq 6,5 \%)$ at the beginning. Then, the number declined to $26.7 \%$ after patients received an education with the booklet handout. The result indicated that the $\mathrm{A} 1 \mathrm{C}$ levels before the intervention were significantly different from the A1C levels after the intervention $(\mathrm{p}=0,005)$. The mean A1C level was $7,56 \pm 1,17 \%$ at the beginning and decreased after education using booklet handout $(5,67 \pm 1,07)$. This can be concluded that education with the booklet handout improves the A1C level and increase medication adherence in patients with type-2 DM. The research conducted in two other primary healthcare centers was similar in results. The patient's glycaemic controls were mostly considered poor before the intervention (mean HbAlc $7.83 \pm 1.59$ and $7.93 \pm 1.26$ ) and rose significantly $(\mathrm{p}=0.005)$ after three months of intervention's period (mean HbA1c 5.41 \pm 1.34 and $5.52 \pm 0.64$ ) (Viviandhari et al., 2018; Wulandari et al., 2020).

\section{The relationship between patient's characteristics and A1C level}

A Chi-Square test was performed to assess the relationship between the patient's characteristics (sociodemographic, clinical, and lifestyle characteristics) and A1C levels. This test was used to assess the factors that influence the A1C levels. 
Table 5. The factors affecting A1C level

\begin{tabular}{llc}
\hline Type & Characteristic & P value \\
\hline Socio- & Gender & 0.295 \\
demographic & Age & 0.099 \\
Characteristic & Level of education & 0.600 \\
& Occupation & 0.377 \\
Clinical & History/duration of & 0.064 \\
Characteristic & type-2 DM & \\
& The numbers of oral & - \\
& antidiabetic drug & 0.724 \\
& Comorbidity & 0.783 \\
& Other medicines Drug & 0.460 \\
& Adverse & \\
Lifestyle & Reaction/side effect & 0.409 \\
Characteristic & Dietary habit & - \\
& Smoking & 0.440 \\
& Exercise & 0.377 \\
\hline
\end{tabular}

In this study, there was no factor from patient's characteristics related to A1C level. This may be due to the limited number of samples. Many pieces of research stated that patient's characteristics were associated with glycemic control. A study stated that poor glycemic control was found in young patients ( $<30$ years old) (Feldman et al., 2014). Unemployed patients prove to have lower glycemic control (Haghighatpanah et al., 2018). Other researches stated that patients without comorbidities had better glycemic control; patients with poor glycemic control had been suffering from type-2 DM for more than 5 years; and patients with a high number of drugs have poor glycemic control (Haghighatpanah et al., 2018; Kassahun et al., 2016).

Prior studies were conducted in two different places (primary healthcare center [2016] and hospital [2017]). A combination of public counseling and booklet handout was used as an education model at Kebon Pala and Makasar primary health care centers in East Jakarta. The research found out that $63.3 \%$ of respondents who followed the study period had A1C level $>7 \%$ initially. After 3 months of study, the number of respondents who had A1C level $>7 \%$ significantly decreased to $23.3 \%$ ( $\mathrm{p}<0.05$ ), respectively. It can be concluded that education intervention with public counseling and booklet handout is effective to improve the type-2 DM patient's glycemic control (Wulandari et al., 2017).

A study in 2017 at Pondok Kopi Hospital, which assessed patient's glycemic control with the help of a family member as a drug supervisor, found out that the mean A1C level of the respondents before the education intervention was $7.2 \%$. The mean $\mathrm{A} 1 \mathrm{C}$ level was significantly declined after the education intervention to 5.5\% ( $\mathrm{P}<0.05)$ (Viviandhari and Wulandari, 2017). This study and prior study recruited respondents from primary health care centers in East Jakarta but used different education intervention models. Booklet handout alone also improves the patient's glycemic control significantly.

Compliance with diabetes mellitus therapy is considered one of the critical aspects of type-2 DM management. Medication adherence in diabetes mellitus is related to better glycemic control, better control of risk factors, lower risk of hospitalization, lower health care cost, and lower risk of mortality (Care, 2019; Kirkman et al., 2015). Implementing diabetes management services requires many aspects such as effort, resources, communication skills, and time commitment. Giving routine education to increase the patient's understanding about the disease itself and the medication to patients made glycemic control achievable. The vital roles of pharmacists in diabetes management are: to screen the patients who are at high risk for developing diabetes, determining 
patient's health status and compliance to diabetes therapy, informing patients with understanding the illness and diabetes mellitus therapy to empower them to self-manage their disease in partnership with health care professionals so that the patients involved and being responsible with their monitoring and therapy outcomes (Hughes et al., 2017).

Research in Indonesia found a limited number of pharmacists in Indonesia's primary healthcare center (Supardi and Susyanti, 2012). This finding made personal education by the pharmacist to patients through personal counseling become difficult to be implemented. Research by Merakou et al. (2015) in a primary health care center in Greece showed that group-based education is more effective in diabetes self-care than individual-based education for type-2 DM patients. In other words, booklet handout, public counseling, and educational video become an effective and cost-efficient alternative in diabetes mellitus education.

This research limitation was the sample size, which is considered inadequate to generalize the Jakarta population's; therefore, bigger sample size and wider coverage area of the healthcare center are needed. Another limitation of this study was that there were no parameters used to ensure that the patients reread the booklet handout at home and understand the information given; therefore, knowledge level analysis is needed.

\section{CONCLUSION}

Booklet handout as an educational intervention effectively improves glycemic control in type-2 diabetes mellitus patients. Either booklet handout, public counseling, or video effectively improve glycemic control in type- 2 diabetes mellitus patients.

\section{ACKNOWLEDGEMENT}

The authors acknowledge all pharmacists and other health professionals at Malaka Jaya Primary Healthcare Centre involved in this research.

\section{REFERENCES}

Aikens, J. E., \& Piette, J. D. (2013). Longitudinal association between medication adherence and glycaemic control in Type 2 diabetes. Diabetic Medicine, 30(3), 338-344. https://doi.org/10.1111/dme.12046

Alfian, S. D., Sukandar, H., Lestari, K., \& Abdulah, R. (2016). Medication adherence contributes to an improved quality of life in type 2 diabetes mellitus patients: a cross-sectional study. Diabetes Therapy, 7(4), 755-764. https://doi.org/10.1007/s13300-016-0203-X

Alldredge, B. K., Corelli, R. L., Ernst, M. E., Guglielmo, B. J., Jacobson, P. A., Kradjan, W. A., \& Williams, B. R. (2013). Koda-Kimble andYoung's Applied Therapeutics: the Clinical Use of Drugs. In Wolters Kluwer, Lippincott Williams \& Wilkins (Issue tenth edition). https://doi.org/10.1017/CBO9781107415324.004

Alqarni, A. M., Alrahbeni, T., Al Qarni, A., \& Al Qarni, H. M. (2019). Adherence to diabetes medication among diabetic patients in the Bisha governorate of Saudi Arabia - a crosssectional survey. Patient Preference and Adherence, 13, 63-71. https://doi.org/10.2147/PPA.S176355

American Diabetes Association. (2003). Treatment of hypertension in adults with diabetes. Diabetes Care, 26(suppl 1), S80-S82. https://doi.org/10.2337/DIACARE.26.2007.S80

American Diabetes Association (ADA). (2017). Standards of medical care in diabetes - 2017. Diabetes Care, 40 (sup 1)(January), s4-s128. https://doi.org/10.2337/dc17-S001

Badan Penelitian dan Pengembangan Kesehatan. (2013). Riset kesehatan dasar (RISKESDAS) 2013. Laporan Nasional 2013, 1-384. https://doi.org/1 Desember 2013

Care, D. (2019). Glycemic targets: standards of medical care in diabetes 2019. Diabetes Care, 42(January), S61-S70. https://doi.org/10.2337/dc19-S006

CDC. (2014). Smoking and diabetes: How smoking causes type 2 diabetes. 
Chang, S. A. (2012). Smoking and type 2 diabetes mellitus. Diabetes and Metabolism Journal, 36(6), 399-403. https://doi.org/10.4093/dmj.2012.36.6.399

Chaudhury, A., Duvoor, C., Reddy Dendi, V. S., Kraleti, S., Chada, A., Ravilla, R., Marco, A., Shekhawat, N. S., Montales, M. T., Kuriakose, K., Sasapu, A., Beebe, A., Patil, N., Musham, C. K., Lohani, G. P., \& Mirza, W. (2017). Clinical review of antidiabetic drugs: Implications for type 2 diabetes mellitus management. Frontiers in Endocrinology, 8(JAN). https://doi.org/10.3389/fendo.2017.0006

Colberg, S. R., Sigal, R. J., Yardley, J. E., Riddell, M. C., Dunstan, D. W., Dempsey, P. C., Horton, E. S., Castorino, K., \& Tate, D. F. (2016). Physical activity/exercise and diabetes: A position statement of the American Diabetes Association. Diabetes Care, 39(11), 2065-2079. https://doi.org/10.2337/dc16-1728

Contreras, F., Sanchez, M., Martinez, M. S., Castillo, M. C., Mindiola, A., Bermudez, V., \& Velasco, M. (2017). Management and education in patients with diabetes mellitus. IMedPub Journals: Medical \& Clinical Reviews, 03(02), 1-7. https://doi.org/10.21767/2471299x.1000049

DiPiro, J. T., Wells, B. G., Schwinghammer, T. L., \& DiPiro, C. V. (2015). Pharmacotherapy handbook.

Elsous, A., Radwan, M., Al-Sharif, H., \& Mustafa, A. A. (2017). Medications adherence and associated factors among patients with type 2 diabetes mellitus in the Gaza Strip, Palestine. Frontiers in Endocrinology, 8(JUN), 1-9. https://doi.org/10.3389/fendo.2017.00100

Fan, M. H., Huang, B. T., Tang, Y. C., Han, X. H., Dong, W. W., \& Wang, L. X. (2016). Effect of individualized diabetes education for type 2 diabetes mellitus: A single-center randomized clinical trial. African Health Sciences, 16(4), 1157-1162. https://doi.org/10.4314/ahs.v16i4.34

Feldman, B. S., Cohen-Stavi, C. J., Leibowitz, M., Hoshen, M. B., Singer, S. R., Bitterman, H., Lieberman, N., \& Balicer, R. D. (2014). Defining the role of medication adherence in poor glycemic control among a general adult population with diabetes. PLOS ONE, 9(9). https://doi.org/10.1371/journal.pone.0108145

Geest, S. De, \& Sabaté, E. (2003). Adherence to long-term therapies: Evidence for action. European Journal of Cardiovascular Nursing, 2(4), 323. https://doi.org/10.1016/S14745151(03)00091-4

Gimenes, H., Zanetti, M., \& Vanderlei, J. (2009). Factors related to patient adherence to antidiabetic drug therapy. Revista Latinoam Enfermagem, 17(1), 46-51. https://doi.org/10.1590/S0104-11692009000100008

Gordon, J., McEwan, P., Idris, I., Evans, M., \& Puelles, J. (2018). Treatment choice, medication adherence and glycemic efficacy in people with type 2 diabetes: A UK clinical practice database study. BMJ Open Diabetes Research and Care, 6(1), 1-9. https://doi.org/10.1136/bmjdrc-2018-000512

Grant, R. W., Devita, N. G., Singer, D. E., \& Meigs, J. B. (2003). Polypharmacy and medication adherence in patients with type 2 diabetes. Diabetes Care, 26(5), 1408-1412. https://doi.org/10.2337/diacare.26.5.1408

Haghighatpanah, M., Nejad, A. S. M., Haghighatpanah, M., Thunga, G., \& Mallayasamy, S. (2018). Factors that correlate with poor glycemic control in type 2 diabetes mellitus patients with complications. Osong Public Health and Research Perspectives, 9(4), 167-174. https://doi.org/10.24171/j.phrp.2018.9.4.05

Hughes, J. D., Wibowo, Y., Sunderland, B., \& Hoti, K. (2017). The role of the pharmacist in the management of type 2 diabetes: currentinsights and future directions. Integrated Pharmacy Research and Practice, 6, 15-27. https://doi.org/10.2147/IPRP.S103783

Kassahun, T., Eshetie, T., \& Gesesew, H. (2016). Factors associated with glycemic control among adult patients with type 2 diabetes mellitus: a cross-sectional survey in ethiopia endocrine 
disorders. BMC Research Notes, 9(1), 1-6. https://doi.org/10.1186/s13104-016-1896-7

Kirkman, M. S., Briscoe, V. J., Clark, N., Florez, H., Haas, L. B., Halter, J. B., Huang, E. S., Korytkowski, M. T., Munshi, M. N., Odegard, P. S., Pratley, R. E., \& Swift, C. S. (2012). Diabetes in older adults. Diabetes Care, 35(12), 2650-2664. https://doi.org/10.2337/dc121801

Kirkman, M. S., Rowan-Martin, M. T., Levin, R., Fonseca, V. A., Schmittdiel, J. A., Herman, W. H., \& Aubert, R. E. (2015). Determinants of adherence to diabetes medications: Findings from a large pharmacy claims database. Diabetes Care, 38(4), 604-609. https://doi.org/10.2337/dc14-2098

Mamo, Y., Bekele, F., Nigussie, T., \& Zewudie, A. (2019). Determinants of poor glycemic control among adult patients with type 2 diabetes mellitus in Jimma University Medical Center, Jimma zone, south west Ethiopia: A case control study. BMC Endocrine Disorders, 19(1), 111. https://doi.org/10.1186/s12902-019-0421-0

Merakou, K., Knithaki, A., Karageorgos, G., Theodoridis, D., \& Barbouni, A. (2015). Group patient education: Effectiveness of a brief intervention in people with type 2 diabetes mellitus in primary health care in Greece: A clinically controlled trial. Health Education Research, 30(2), 223-232. https://doi.org/10.1093/her/cyv001

Munger, M. A. (2010). Polypharmacy and combination therapy in the management of hypertension in elderly patients with co-morbid diabetes mellitus. Drugs and Aging, 27(11), 871-883. https://doi.org/10.2165/11538650-000000000-00000

Nanda, O. D., Wiryanto, R. B., \& Triyono, E. A. (2018). Hubungan Kepatuhan Minum Obat Anti Diabetik dengan Regulasi Kadar Gula Darah pada Pasien Perempuan Diabetes Mellitus Relationship between Antidiabetic Drugs Consumption and Blood Glucose Level Regulation for Diabetes Mellitus Female 340-348. https://doi.org/10.20473/amnt.v2.i4.2018.340-348

PERKENI. (2015). Konsensus pengendalian dan pencegahan diabetes melitus tipe 2 di Indonesia 2015. In Perkeni. https://doi.org/10.1017/CBO9781107415324.004

Polonsky, W. H., \& Henry, R. R. (2016). Poor medication adherence in type 2 diabetes: Recognizing the scope of the problem and its key contributors. Patient Preference and Adherence, 10, 1299-1306. https://doi.org/10.2147/PPA.S106821

Puspitasari, A. W., R.Andrajati, \& A.Bahtiar. (2013). Analisis efektivitas booklet obat terhadap tingkat kepatuhan pasien diabetes melitus tipe-2. Journal of Management and Pharmacy Practice, 2, 1-7.

Rasdianah, N., Martodiharjo, S., Andayani, T. M., \& Hakim, L. (2016). The Description of Medication Adherence for Patients of Diabetes Mellitus Type 2 in Public Health Center Yogyakarta. Indonesian Journal of Clinical Pharmacy, 5(4), 249-257. https://doi.org/10.15416/ijcp.2016.5.4.249

Riskesdas. (2018). Hasil utama riskesdas penyakit tidak menular 2018. Hasil Utama Riskesdas Penyakit Tidak Menular, 8.

Sacks, D. B., Arnold, M., Bakris, G. L., Bruns, D. E., Horvath, A. R., Kirkman, M. S., Lernmark, A., Metzger, B. E., \& Nathan, D. M. (2011). Guidelines and recommendations for laboratory analysis in the diagnosis and management of diabetes mellitus. Diabetes Care, 34(6). https://doi.org/10.2337/dc11-9998

Sami, W., Ansari, T., Butt, N. S., \& Hamid, M. R. A. (2017). Effect of diet on type 2 diabetes mellitus: A review. International Journal of Health Sciences, 11(2), 65-71. https://doi.org/10.1002/dmrr.2515

Samu, A. M., Amirthalingam, P. S., \& Mohammed, O. S. (2017). Assessment of patient medication adherence among the type 2 diabetes mellitus population with peripheral diabetic neuropathy in South India. Journal of Taibah University Medical Sciences, 12(2), 164-168. https://doi.org/10.1016/j.jtumed.2016.12.006 
Shang, X., Li, J., Tao, Q., Li, J., Li, X., Zhang, L., Liu, X., Wang, Q., Shi, X., Zhao, Y., Hu, S., Jiang, L., \& Yang, Y. (2013). Educational Level, Obesity and Incidence of Diabetes among Chinese Adult Men and Women Aged 18-59 Years Old: An 11-Year Follow-Up Study. PLoS ONE, 8(6). https://doi.org/10.1371/journal.pone.0066479

Sharma, T., Kalra, J., Dhasmana, D., \& Basera, H. (2014). Poor adherence to treatment: A major challenge in diabetes. Journal, Indian Academy of Clinical Medicine, 15(1), 26-29.

Steinsbekk, A., Rygg, L., Lisulo, M., By Rise, M., \& Fretheim, A. (2015). Group based diabetes self-management education compared to routine treatment, waiting list control or no intervention for people with type 2 diabetes mellitus. Cochrane Database of Systematic Reviews, 2017(12). https://doi.org/10.1002/14651858.CD003417.pub3

Supardi, S., \& Susyanti, A. L. (2012). Kebijakan penempatan apoteker di puskesmas. Buletin Penelitian Sistem Kesehatan, 15, 133-142.

Trisnawati, S. K., \& Setyorogo, S. (2013). Faktor Risiko Kejadian Diabetes Melitus Tipe II Di Puskesmas Kecamatan Cengkareng Jakarta Barat Tahun 2012. Jurnal Ilmiah Kesehatan, 5(1), 6-11.

Viviandhari, D., \& Wulandari, N. (2017). Edukasi pada pengawas minum obat dan pasien diabet millitus tipe 2 untuk meningkatkan kepatuhan minum obat. Media Farmasi: Jurnal Ilmu Farmasi, 14(2), 162-176. https://doi.org/10.12928/mf.v14i2.11242

Viviandhari, D., Wulandari, N., \& Puspita, F. P. (2018). Public counseling: an educational model to improve medication adherence in type 2 diabetes mellitus patients. Proceeding of the First Muhammadiyah International Conference on Health and Pharmaceutical Development, 7176. https://doi.org/10.5220/0008239600710076

Waari, G., Mutai, J., \& Gikunju, J. (2018). Medication adherence and factors associated with poor adherence among type 2 diabetes mellitus patients on follow-up at Kenyatta National Hospital, Kenya. Pan African 29. https://doi.org/10.11604/pamj.2018.29.82.12639

Wabe, N. T., Angamo, M. T., \& Hussein, S. (2011). Medication adherence in diabetes mellitus and self management practices among type-2 diabetics in Ethiopia. In North American Journal of Medical Sciences (Vol. 3, Issue 9, pp. 418-423). https://doi.org/10.4297/najms.2011.3418

Wulandari, N., Viviandhari, D., \& Nurhayati. (2017). A strategic approach to increase the compliance of patients with type 2 diabetes mellitus, in unity in diversity and the standardisation of clinical pharmacy services. In Z. Elida, Junaidi Khotib., A. Chrismawan, S. Syed Azhar Syed, S. I. Charles D., \& W. Timothy E. (Eds.), Proceedings of the 17th Asian Conference on Clinical Pharmacy (ACCP 2017). CRC Press/Balkema.ISBN: 978-1-13808172-7 (Hbk) ISBN: 978-1-315-11275-6 (eBook)

Wulandari, N., Viviandhari, D., \& Seli Febriani, A. (2020). Educational Video to Improve Glycemic Control of Type 2 Diabetes Mellitus Patients. Jurnal Manajemen Dan Pelayanan Farmasi, 10(4), 276-283. 